DOI 10.37882/2500-3682.2021.01.11

\title{
НОВАЯ МОДЕЛЬ ВИЗИОНЕРСТВА В МЕДИАКУЛЬТУРЕ
}

\section{A NEW MODEL OF VISIONARY ACTIVITY IN MEDIA CULTURE}

\section{A. Pozharov}

Summary: The article analyzes the media popularity of eco-activist Greta Thunberg as a cultural phenomenon based on the traditional Christian archetype of visionary children. The historical analogies of the phenomenon are considered, its structural scheme is revealed, and a brief scientific assessment of the concept of visionary is given. What makes Greta Thunberg different from other visionary children known in Western European history? What are the cultural trends of modern society indicated by the phenomenon of its popularity?

Keywords: semiotics, Greta Thunberg, visionary, cultural studies.
Пожаров Алексей Игоревич

Канд. культурологии, член Российского Музыкального Союза, доцент, Институт кино и телевидения (ГИТР) Soundman.alex@gmail.com

Аннотация: В статье проводится анализ медийной популярности экоактивистки Греты Тунберг как культурного феномена, базирующегося на традиционном христианском архетипе детей-визионеров. Рассмотрены исторические аналогии феномена, выявлена его структурная схема и дана краткая научная оценка понятию визионерства. Что принципиально отличает Грету Тунберг от других известных в западноевропейской истории детей-визионеров? На какие культурные тенденции современного общества указывает феномен ее популярности?

Ключевые слова: семиотика, Грета Тунберг, визионерство, культурология.
11 февраля 1858 года Бернадетта Субиру, четырнадцатилетняя французская девочка, собирала хворост у маленького грота неподалеку от Лурда, когда увидела необъяснимое свечение, из которого выступила небольшая фигура женщины в бело-голубом одеянии, которую девочка назвала «барышней». На протяжении нескольких месяцев Бернадетта приходила к гроту.

Сначала видение было безмолвным, но затем женщина начала говорить о покаянии, необходимости молитвы за грешников, описывала лежащий во грехе мир и повелела построить в месте её явления часовню. «Је ne vous promets pas de vous rendre heureuse en ce monde, mais dans l'autre» (Я не обещаю сделать вас счастливыми в этом мире, но это будет в другом). Мы знаем мир насилия, обмана, хрупкости и бизнеса от войны, но мы также знаем мир благотворительности, солидарности, справедливости. Когда Иисус в Евангелии призывает нас обнаружить Царство Небесное, он приглашает нас открыть для себя мир как он есть и «другой мир». Там, где есть любовь, Бог присутствует. [6] Призыв к покаянию был услышан - к шестому видению в грот вместе с девочкой приходит около ста крестьян из окрестных селений. В первой статье, появившейся в местной газете, говорилось о «девочке, по всем признакам, подверженной каталепсии, будоражащей любопытство лурдского населения». Со всех сторон ей запрещали возвращаться в грот - к счастью, эти запреты были отменены, когда, - как пишет А. Сикари, - к чуду «проявили любопытство некоторые влиятельные лица» [9, с. 168] из числа высшего духовенства. На девятом видении Бернадетта, выполняя аскезу по приказу женщины, пьет грязную воду в углу грота и ест растущую там траву. На следую-

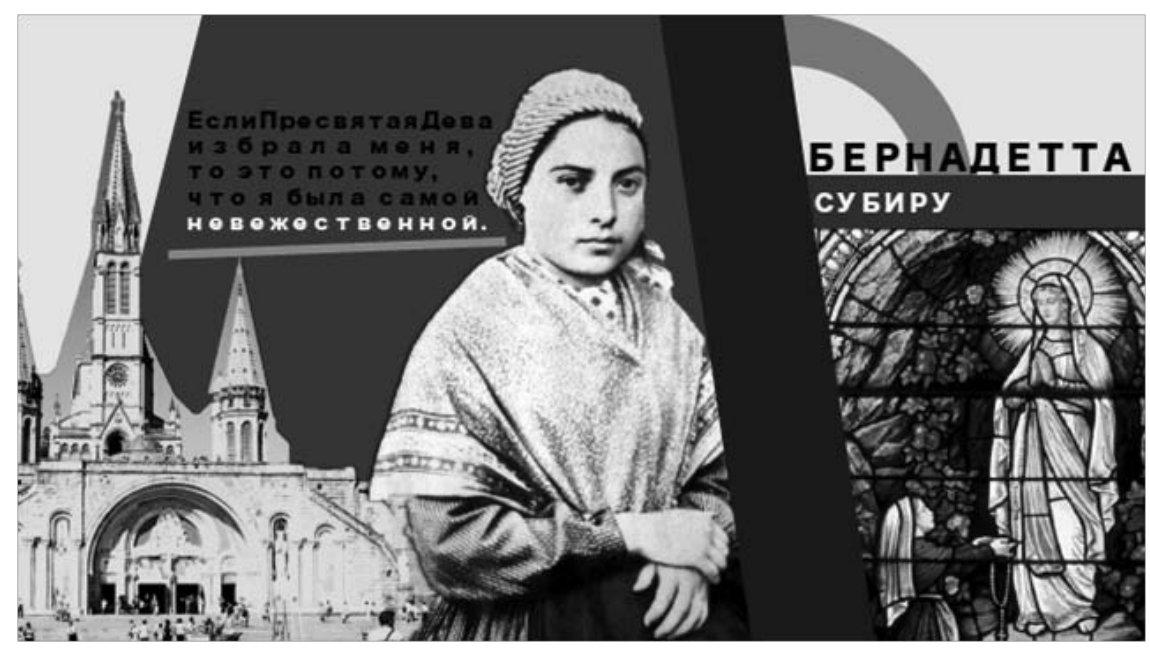

Рис. 1. Бернадетта Субиру 
щее явление на этом месте появится родник. После неоднократных просьб назваться, на одиннадцатом видении женщина говорит, что она - «Непорочное зачатие», а к пятнадцатому за Бернадеттой следует 8 тысяч человек, - впрочем, видит женщину и разговаривает с ней попрежнему только Бернадетта, которая истово молится, временами впадая в экстаз.

На видения реагирует государственная машина: Бернадетту вызывают в полицию и к местным священникам, которые пытаются доказать вымышленность явлений Богородицы. Власти грозят ей тюрьмой, устраивают ей многочасовые допросы, стремясь сбить ее с толку и добиться от нее признания в том, что она солгала; ей читают фальсифицированные протоколы допросов, которые Бернадетта шаг за шагом исправляет, ни разу не спутавшись и не уступив [9, с. 170]

К последнему же, восемнадцатому явлению полиция оцепляет грот и запрещает туда доступ всем, включая визионерку, и ей приходится молиться перед гротом. Начинается длительное расследование, сначала медики склоняются к версии душевной болезни визионерки, а местное священство недоумевает, отчего видение говорило с Бернадеттой по-окситански. Однако, параллельно с ростом паломников и популярности Лурда, высокопоставленные клирики начинают видеть в явлениях несомненное чудо: как могла необразованная крестьянская девочка назвать появившуюся женщину «Непорочным зачатием», если соответствующий догмат был принят Святейшим Престолом только за четыре года до первого видения?

Бернадетта же со своей стороны настаивает, что она лишь передает волю Небес людям, при этом не пред- ставляя сама из себя ничего значительного: Я не имела никакого права на эту милость. Пресвятая Дева взяла меня, как поднимают камушек с дороги... Если Пресвятая Дева избрала меня, то это потому, что я была самой невежественной. Если бы она нашла какую-нибудь ещё более невежественную, чем я, она избрала бы ее. $[9$, c. 165]

Папская комиссия признаёт явления Богородицы в Лурде подлинными, Бернадетта заканчивает жизнь в монастыре, а через 30 лет будет беатифицирована, причем тело ее при эксгумации будет найдено нетленным. На месте видений построен огромный комплекс, который ежегодно посещают миллионы паломников, получающих исцеление.

В мае 1917 года семилетние португальские крестьянки Лусия душ Сантуш, Франсишку и Жасинта Марту пасли овец в местности, называвшейся Кова-да-Ирия, и их «взорам предстала на скальном дубе Дама, одетая вся в белое и сиявшая ярче солниа». [9, с. 186] Дама попросила детей приходить на это место в течение шести последующих месяцев каждого 13го числа, в это же самое время. Лусия, Франсишку и Жасинта послушались, и в каждое из появлений Дама говорила о необходимости покаяния и о неисчислимых бедствиях, грозящих миру: «Превраmите все, что можете, в жертву, чтобы искупить грехи (...) во имя Христа, Которого так страшно оскорбляют неблагодарные люди, (...) и принесите ее как просьбу за обращение грешников». [9, с. 85]

13 августа дети не смогли посетить назначенное место, так как были задержаны и допрошены полицией по настоятельному требованию правительства Португалии. Детей запирают в участке, где их пытались заставить от-

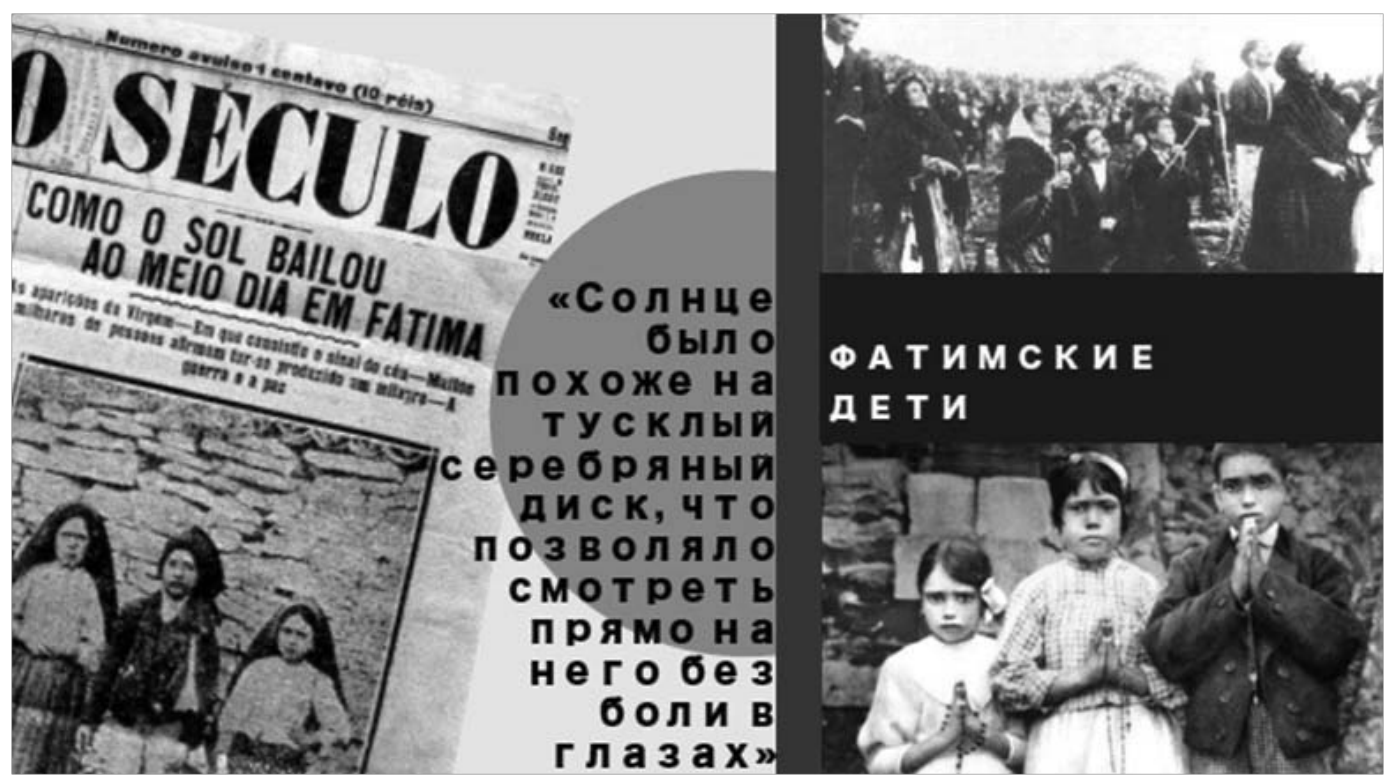

Рис. 2. Фатимские дети 
казаться от своих свидетельств, но дети стояли на своем. Общественное мнение, опираясь на высказывания медиков и священства, относило видения визионеров из бедных, неблагополучных семей к бреду умственно отсталых, малограмотных детей. 13 октября в долине Фатимы собралось около 70 тысяч человек, читающих по четкам молитвы.

По свидетельству собравшихся, они стали свидетелями явления, которое впоследствии получило название «танец солнца» и было описано даже в антиклерикальной прессе: Солнце было похоже на тусклый серебряный диск, что позволяло смотреть прямо на него без боли в глазах. Оно не сжигало глаза. Оно не ослепляло их. Некоторым даже казалось, что началось солнечное затмение. Толпа взорвалась необъятным криком, и тот, кто находился внутри самой толпы слышал выкрики: “Чудо! Чудо! Знамение!...Знамение!..." [17, с. 296]

Популярность Фатимы была столь высока, что 8 июля 1924 года Лусия дает показания специальной диоцезной канонической комиссии, назначенной епископом Лейрийским Жозе Алвешем Коррейа да Силва. По завершении этого процесса, епископ Лейрийский в своем пастырском послании от 13 октября 1930 года относительно культа Пресвятой Девы Марии Фатимской объявил, что «видения детей, имевшие место в Кова-да-Ирия, приход Фатимы в этом диоцезе, заслуживают доверия». [25, с 123-146]

Лусия, единственная визионерка, с которой по ее словам говорила Дама, до конца своей долгой жизни говорила о себе, как о немощном орудии в руках Божьих: Я также не чувствовала совсем здоровыми мое сердие и глаза и др., но необходимо завершить в самой себе недостающее в Страданиях Христа. Необходимо, чтобы члены Нашего Господа были одно с Ним, как через физическую боль, так и через духовные страдания... Наш бедный Господь, Который спас нас с такой любовью, и как мало Он понят! Как мало любим! Как скверно Ему служат! [23]

Я должна благодарить Господа за содействие Его Божественного Духа, потому что чувствую, что Он сообщает мне, что нужно написать или сказать. Если иногда сила моего воображения или же мой ум хотят мне что-то сообщить, то я сразу чувствую, что не хватает Божественного Духа, и жду, пока не почувствую в глубине своей души, что хочет сказать Господь [9, с. 146].

Сейчас признанные католической церковью Фатимские предсказания делятся на три основных: видение Ада и мучений грешников, необходимость покаяния и посвящения русского народа и России Богородице, (впрочем, визионерка записала его в 1924, а обнародовала только в 1929 году, что прекрасно вписывалось в различные пропагандистские компании против СССР, хотя утверждала, что видение было ей даровано летом 1917, то есть когда Россия еще не отторгла веру) и третья, содержащая апокалиптические видения конца света и преданная гласности только в 2000 году: Святейший Отеи прошёл через большой город, наполовину в руинах, наполовину содрогающийся. Он шёл останавливаясь, страдая от боли и горя и молясь за души тех, трупы которых он встречал на своём пути. Достигнув вершины горы, на коленях у подножия Креста он был убит группой солдат, которые стреляли в него пулями и стрелами. И таким же образом там умерли один за другим другие епископы, священники и верующие мужчины и женщины, и различные миряне разных чинов и сословий [7].

На месте явлений Дамы, которую стали отождествлять с Богородицей [25], построен поистине грандиозный комплекс, включающий храмы, огромный конференц-зал, и принимающий миллионы паломников.

20 августа 2018 года шведская школьница Грета Тунберг, озабоченная проблемой глобального потепления из-за выбросов парникового газа, решила не ходить в школу по пятницам и начала выходить с одиночными пикетами к зданию шведского парламента с плакатом «Школьная забастовка за климат» и раздавать прохожим листовки. Вы говорите, что жизнь не чёрно-белая. Но это ложь. Либо мы предотвратим $1,5^{\circ} \mathrm{C}$ потепления, либо нет. Мы или избежим возникновения этой необратимой чепной реакции вне человеческого контроля, или нет... Яхочу, чтобы вы вели себя так, как будто наш дом горит. Потому что как раз это сейчас происходит. <...> Я не хочу, чтобы вы надеялись. Я хочу, чтобы вы запаниковали. Яхочу, чтобы вы почувствовали страх, который я чувствую каждый день. А потом я хочу, чтобы вы начали действовать [24].

7 сентября она объявила, что продолжит бастовать каждую пятницу, пока Швеция не начнет соблюдать Парижское соглашение. Фигура Греты, дочери популярной певицы а по совместительству - диаконессы лютеранской церкви, и Сванте Тунберга известного актера (и, внезапно, правнука знаменитого шведского ученого Сванте Аррениуса, открывшего парниковый эффект в 1896 году) [11], сразу же начинает активно освещаться в медиа. По свидетельству мамы Греты, девочка с детства обладала уникальными визионерскими способностями: Грета принадлежит к тому малому числу людей, что могут видеть углекислый газ невооруженным глазом. Она видела как парниковые газы потоками вытекают из наших печных труб, парят, поднимаясь вверх с ветрами, и преображают атмосферу в гигантскую невидимую свалку [11.].

В Швеции практически моментально появляется движение «Школьная забастовка за климат» (швед. Skolstrejk 


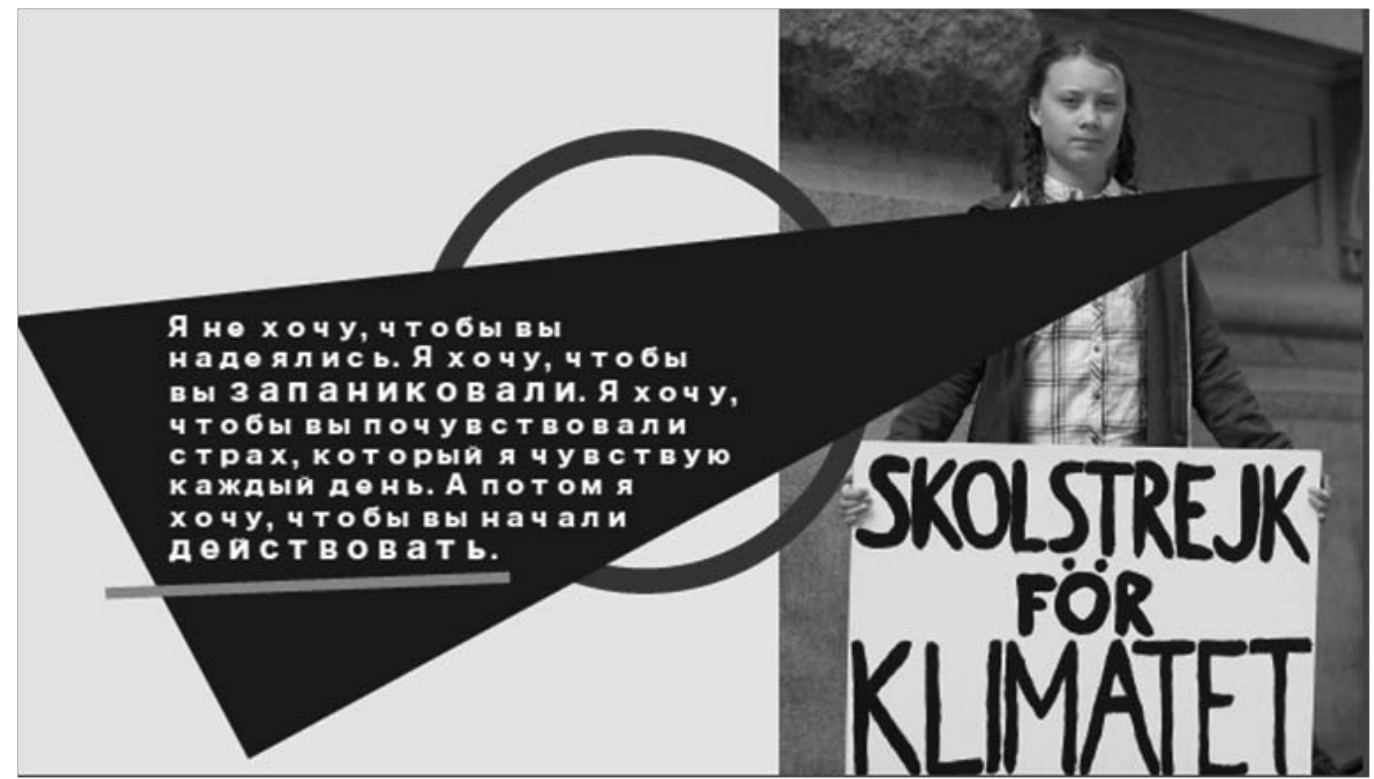

Рис. 3. Грета Тунберг у здания парламента

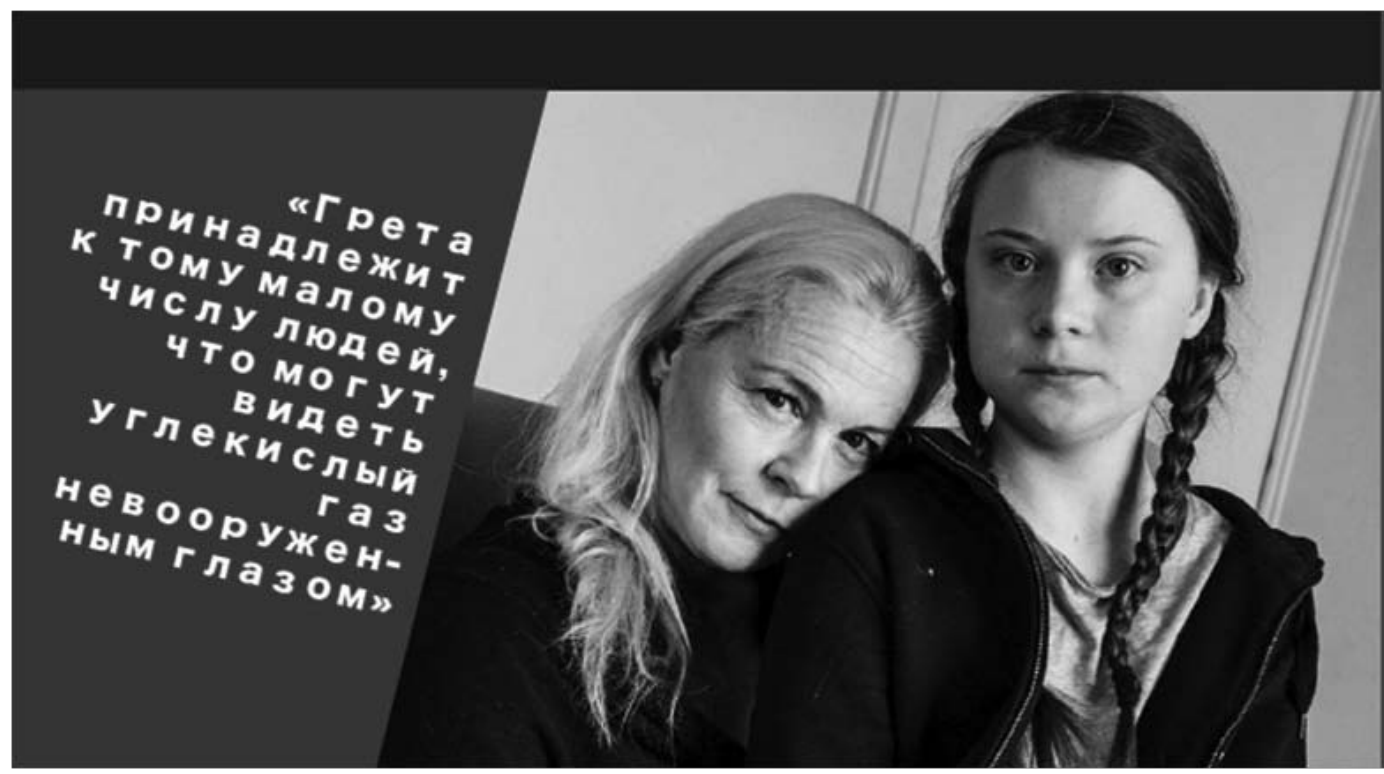

Рис. 4. Грета Тунберг с мамой

för klimatet), получающее мировое распространение под названием «Пятницы ради будущего» (англ. Fridays For Future, FFF). Через три месяца после появления Греты у здания парламента, в декабре 2018 года, во время Конференции ООН об изменении климата организованные студенческие и школьные забастовки в поддержку климатических требований проходят в 270 городах в Австралии, Австрии, Бельгии, Канаде, Голландии, Германии, Финляндии, Японии, Швейцарии, Англии и США [18]. Во время этих выступлений Грета встретилась с генсеком ООН Антониу Гуттерришем, который одобрил забастовки, сказав: «Моему поколению не удалось должным образом отреагировать на серьезную проблему изменения климата. Это было принято близко к сердиу молодёжью. Неудивительно, что они разозлены» [21].
В январе 2019 года Тунберг выступила на Давосском форуме, а в апреле 2019 года встретилась с Папой Римским и получила его благословение: «Храни тебя Господь. Продолжай делать то, что делаешь. Иди вперед!» [12], - так отреагировал Папа Франциск на деятельность Греты.

20 сентября 2019 года на демонстрации в поддержку деятельности Тунберг по всему миру одновременно выходит до шести миллионов человек, а 23 сентября Грета выступает на саммите $\mathrm{OOH}$ по климату со ставшей знаменитой обвинительной речью, в которой обрушивается на мировые правительства, обвиняя их в равнодушии к экологическим проблемам и в том, что они «украли у детей будущее». 


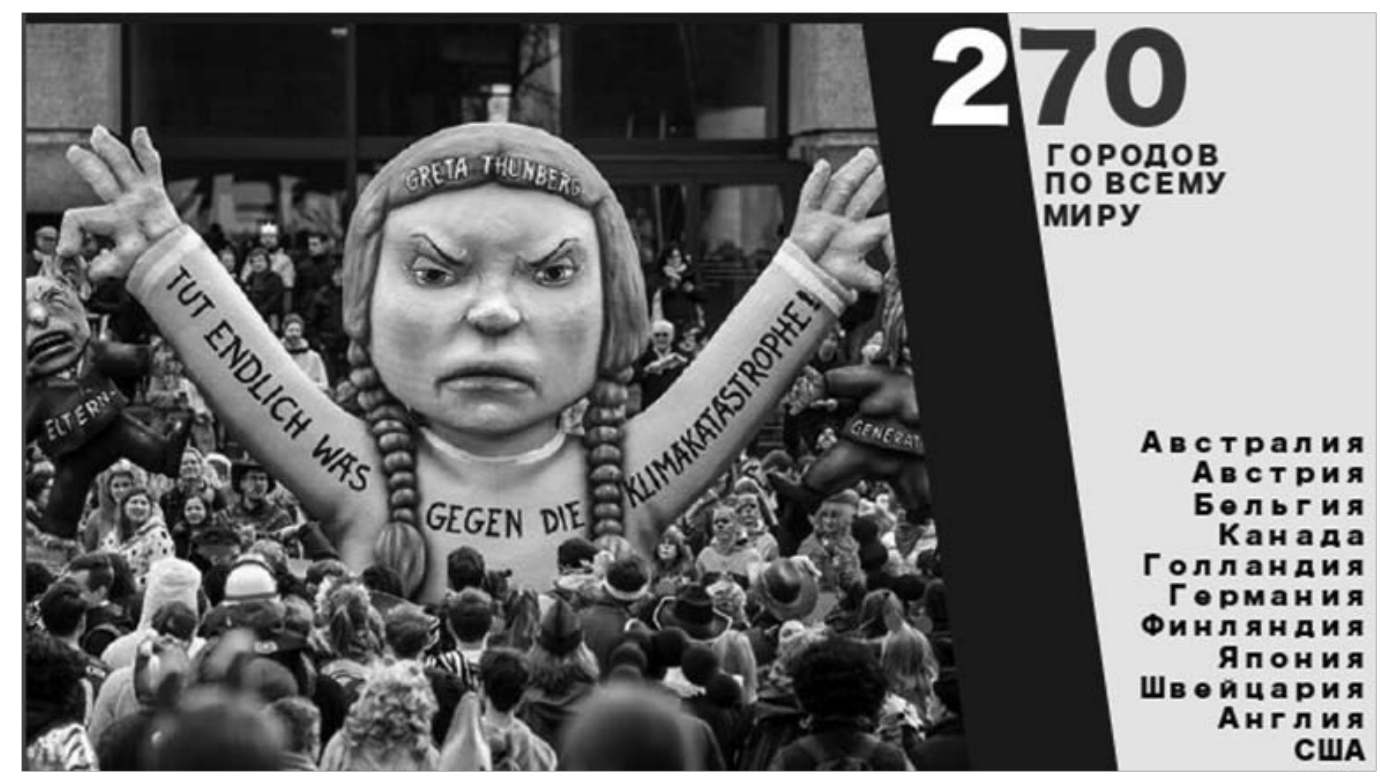

Рис. 5. Манифестации по всему миру

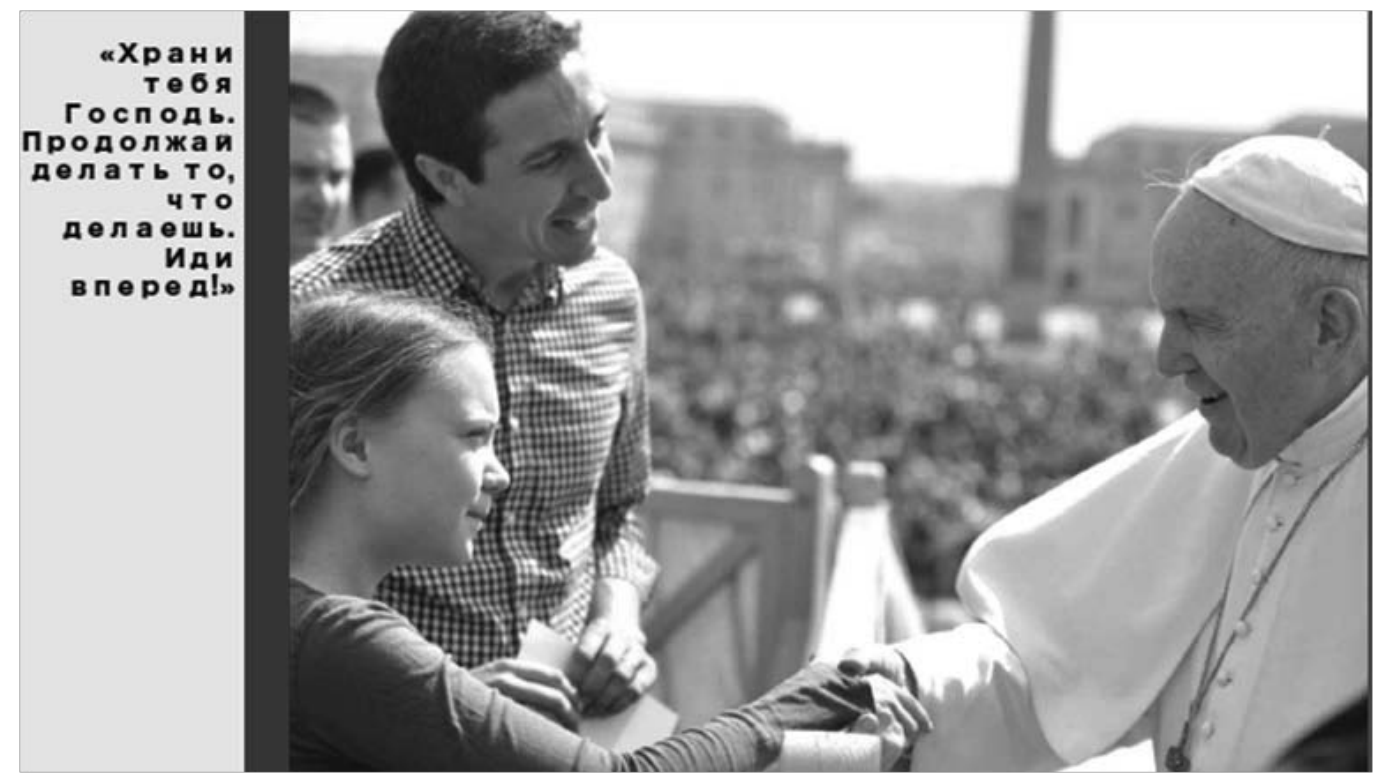

Рис. 6. Папа Франциск и Грета Тунберг

у Греты еще в возрасте 8 лет был выявлен ряд психических отклонений, таких как синдром Аспергера, обсессивно-компульсивное расстройство и селективный мутизм. Тунберг уверена, что она является исключительным человеком, наделенным особыми способностями: Я говорю только когда считаю это необходимым, и сейчас - такой момент [20]. Я обладаю даром видеть мир не таким, как остальные люди [22].

Мало какая медийная личность становится столь популярной и вызывает столько неоднозначных оценок, сколько Грета. Она встречается практически со всеми ведущими политиками современности.

Трамп и Путин дают ей оценки, которые Грета дела- ет названием своего канала в Twitter, одна из них, принадлежащая нашему Президенту, вынесена в заглавие статьи. Робкие отдельные попытки публично выражать несогласие с деятельностью Греты немедленно подвергаются резкой критике в публичном поле: министр экологии Бельгии Жоке Шовигле назвала климатические демонстрации школьников провокациями извне, что привело к скандалу - бельгийские спецслужбы заявили, что не сообщали ничего подобного, после чего Шовигле объявила о своей отставке [19].

Грета выдвигается на Нобелевскую премию мира, а в ожидании её становится лауреатом международной премии Right Livelyhood Award, которую называют альтернативной Нобелевской: «Мы удостоили такой чести 


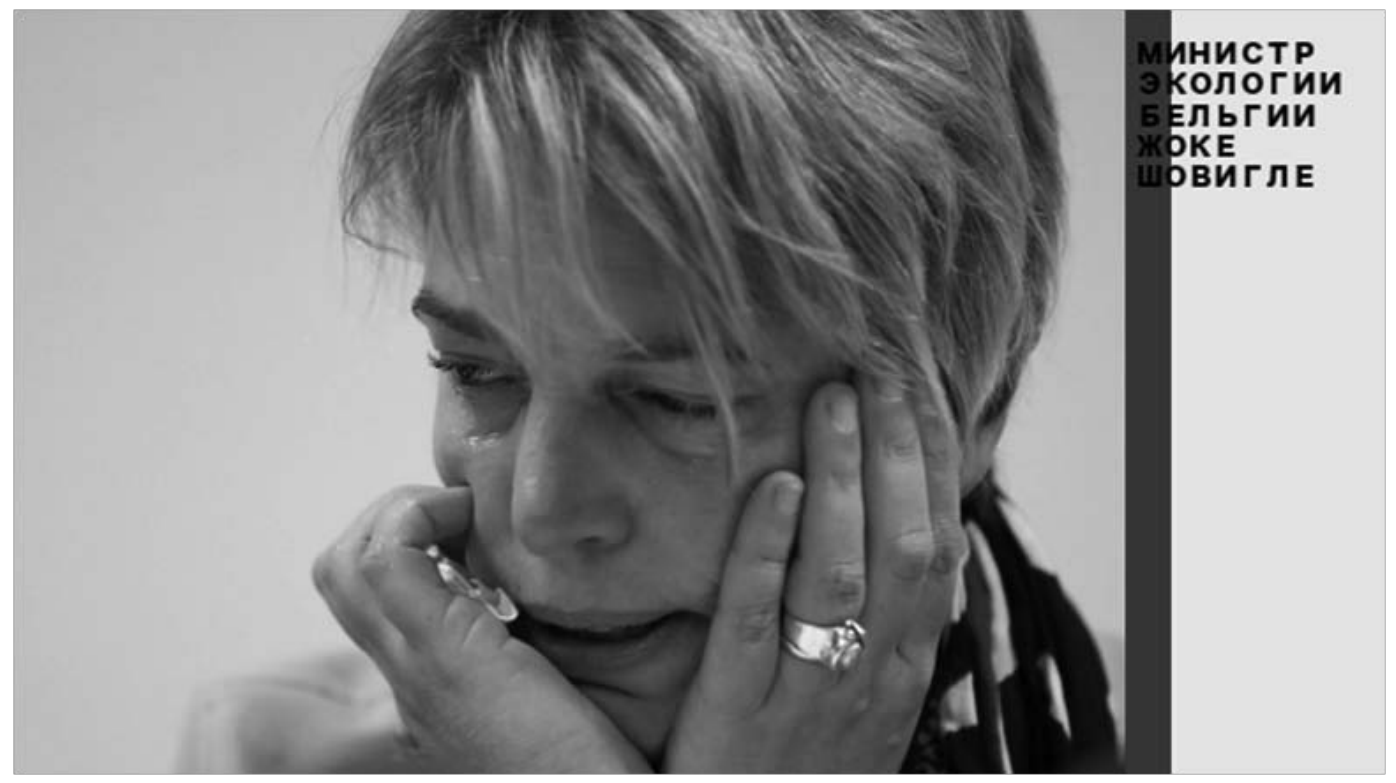

Рис. 7. Министр экологии Бельгии Жоке Шовигле

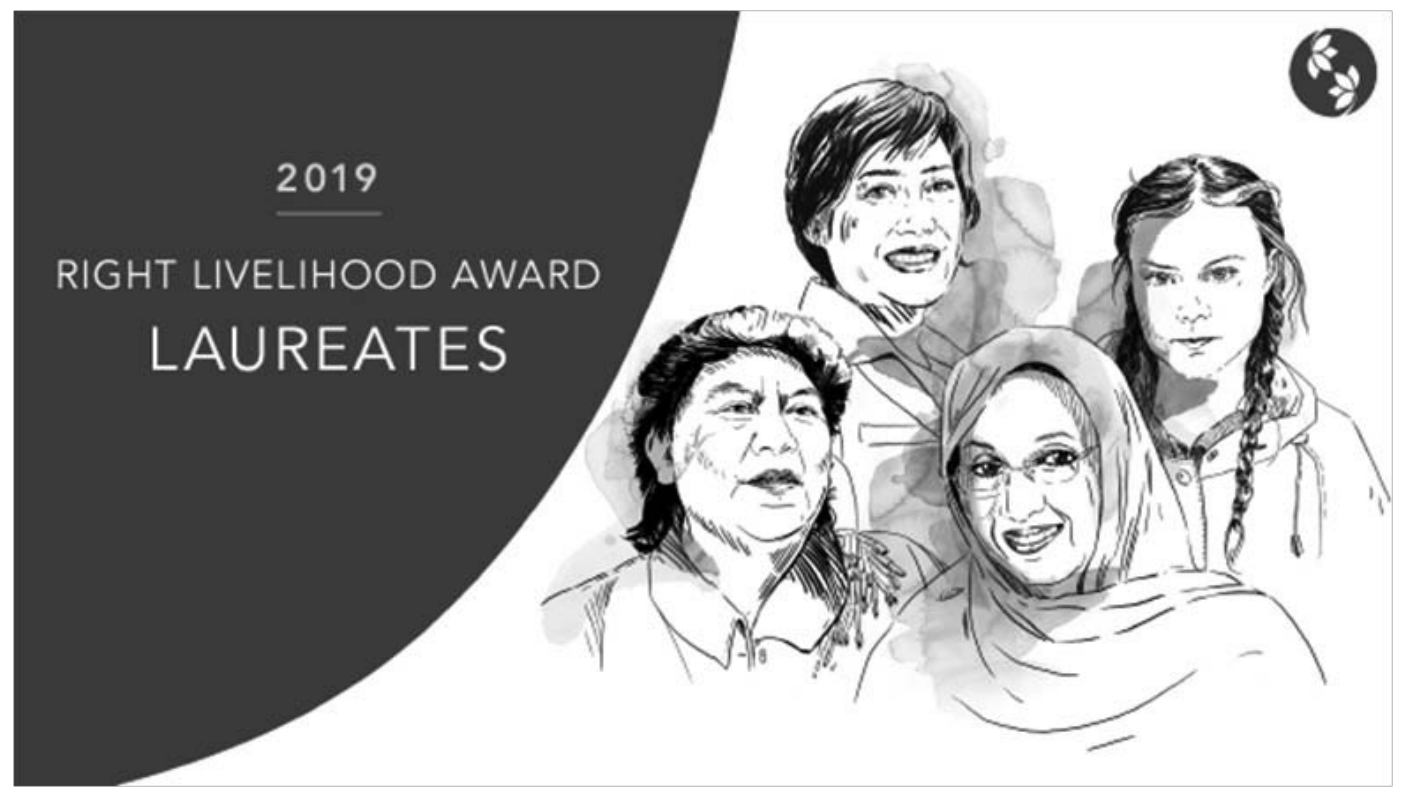

Рис. 8. Премия Right Livelyhood Award

четверых визионеров, чья практическая деятельность позволяет миллионам людей защищать их фундаментальные права и бороться за достойное будущее на этой планете», - заявило жюри [1].

Абсолютным признанием Греты как современной медиаиконы стало объявление её журналом TIME человеком года.

В то же время в сетевом пространстве часто встречаются высказывания людей (не обличенных властью), скептически оценивающих деятельность Тунберг и её фонда.

Моя итальянская корреспондент, выходец из бывше- го СССР, пишет в удаленном посте в комьюнити «Русская Италия»: Это хуже, чем брежневского времени шествия на 7 ноября. Во всём Турине отменены занятия в школах и университетах, детям раздают экологические транспаранты и автобусами вывозят на демонстрации. Вся поличия на охране, движение перекрыто, жизнь в городе остановилась. Ей отвечают: «У нас в городе детям дали задание написать сочинение о важности экологии и приложить к нему список химических средств для ведения хозяйства, имеющихся в доме. Павлик Морозов жив!»

Не обходится, конечно, без конспирологических теорий, склонных связывать феномен популярности Греты с интересами крупных финансовых кланов. В нашу задачу 


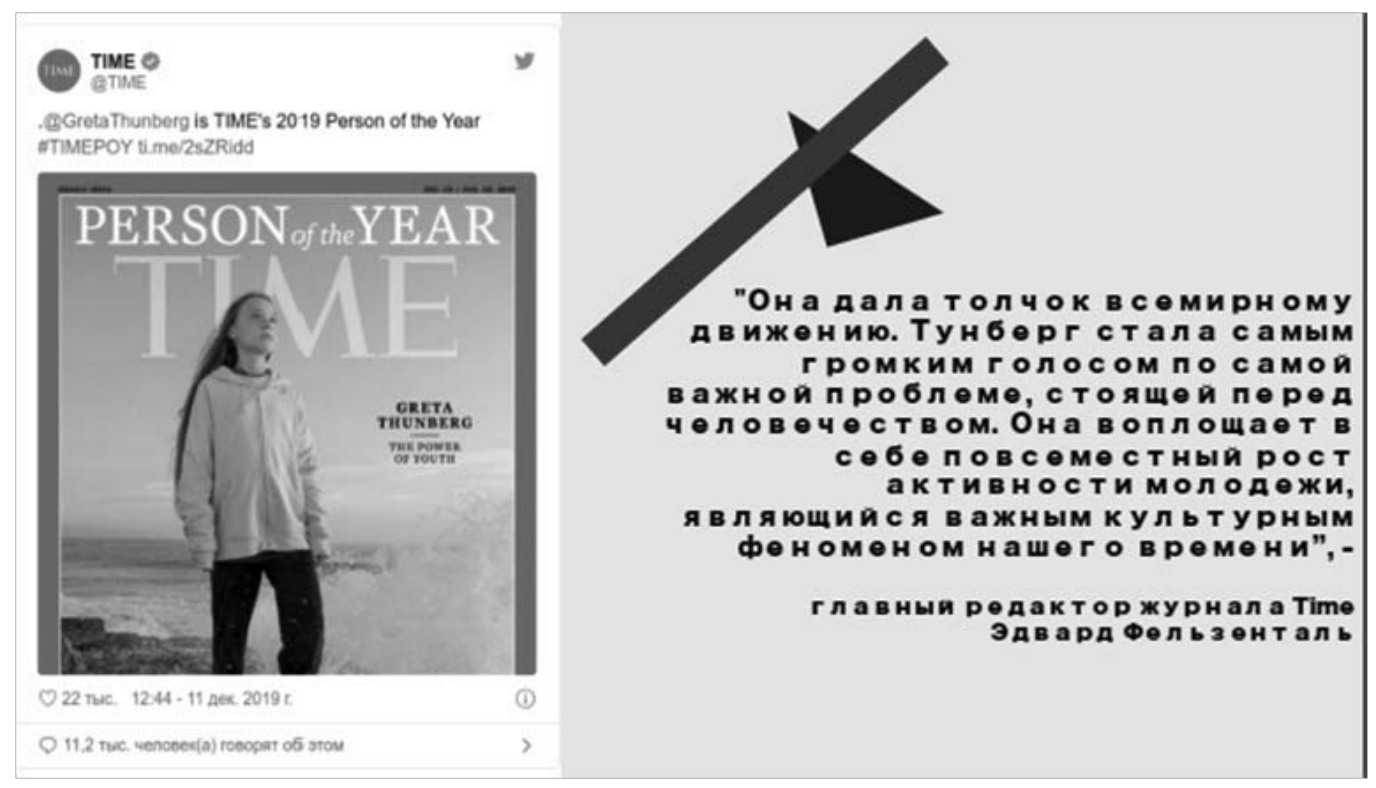

Рис. 9. Грета Тунберг на обложке журнала «Тіме»

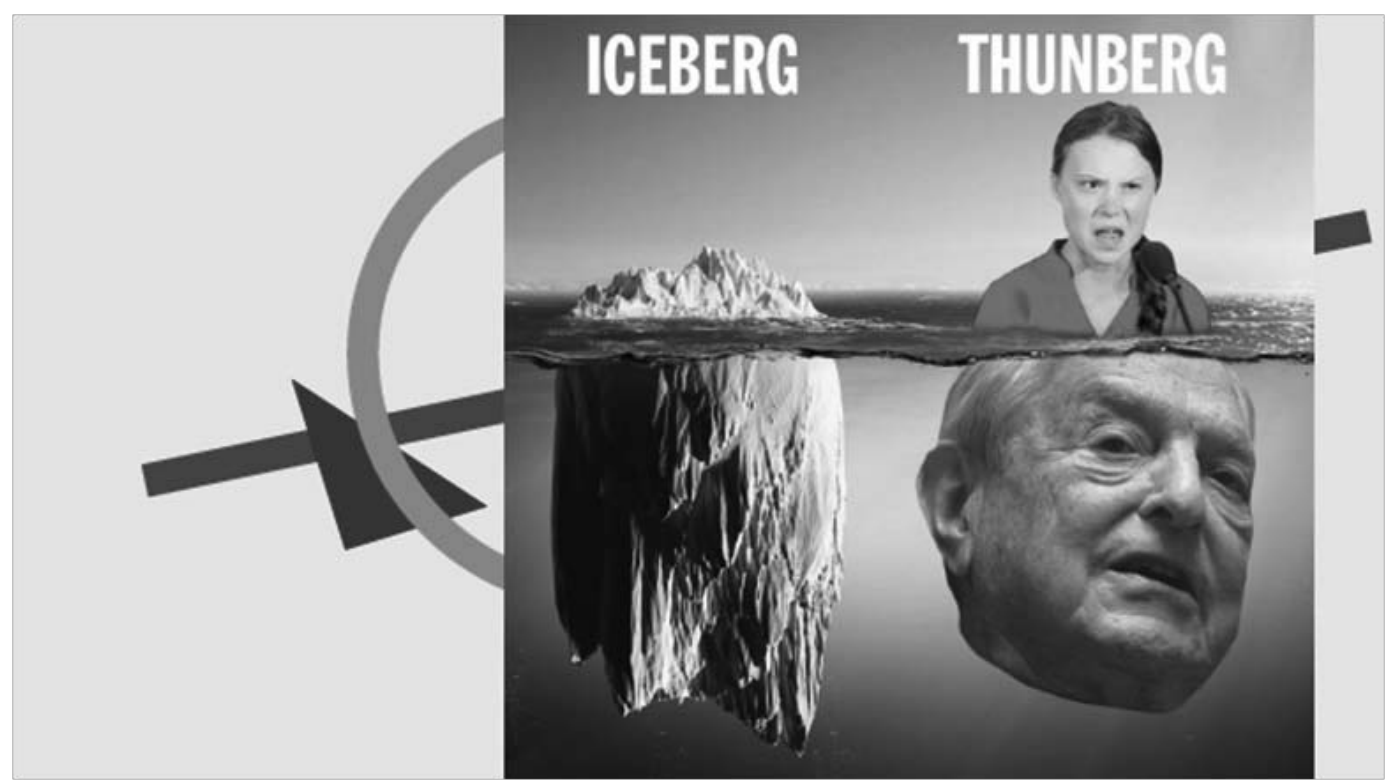

Рис. 10. Карикатура - Грета Тунберг и Ротшильд

не входит анализ предположений «кто стоит за Гретой Тунберг», нас интересует только резонансность её деятельности в контексте трансформации архетипа детского визионерства.

Визионерство как явление связано с развитием духовной культуры человечества, которая задает ему определенные культурно-исторические смыслы. Традиционно визионерство рассматривалось либо как патологическое психофизическое состояние, связанное с определенными девиациями, либо как специфический религиозный либо художественный феномен, который относили либо к мистике, либо к области фантазии, способности «возникновения образа из призраков души ${ }^{[1]}$ » $[16$, c.6].
Существует некоторое количество феноменологических концепций, которые описывают визионерство, оделяя его от других, сходных с ним феноменов, исходя из воздействий на медиума социокультурных факторов. Одним из первых авторов, рассматривавших визионерство в форме философской рефлексии был писатель и философ Олдос Леонард Хаксли, посвятивший этой проблеме эссе «Двери восприятия» (1954) и «Рай и ад» (1956)

Еще одним из аспектов исследования визионерства является его определение, как пограничной формы восприятия, поэтому его часто рассматривали в работах, посвященных исследованиям изменённого сознания такие исследователи от отца трансперсональной психологии С. Гроф, до ряда современных исследователей-неопози- 


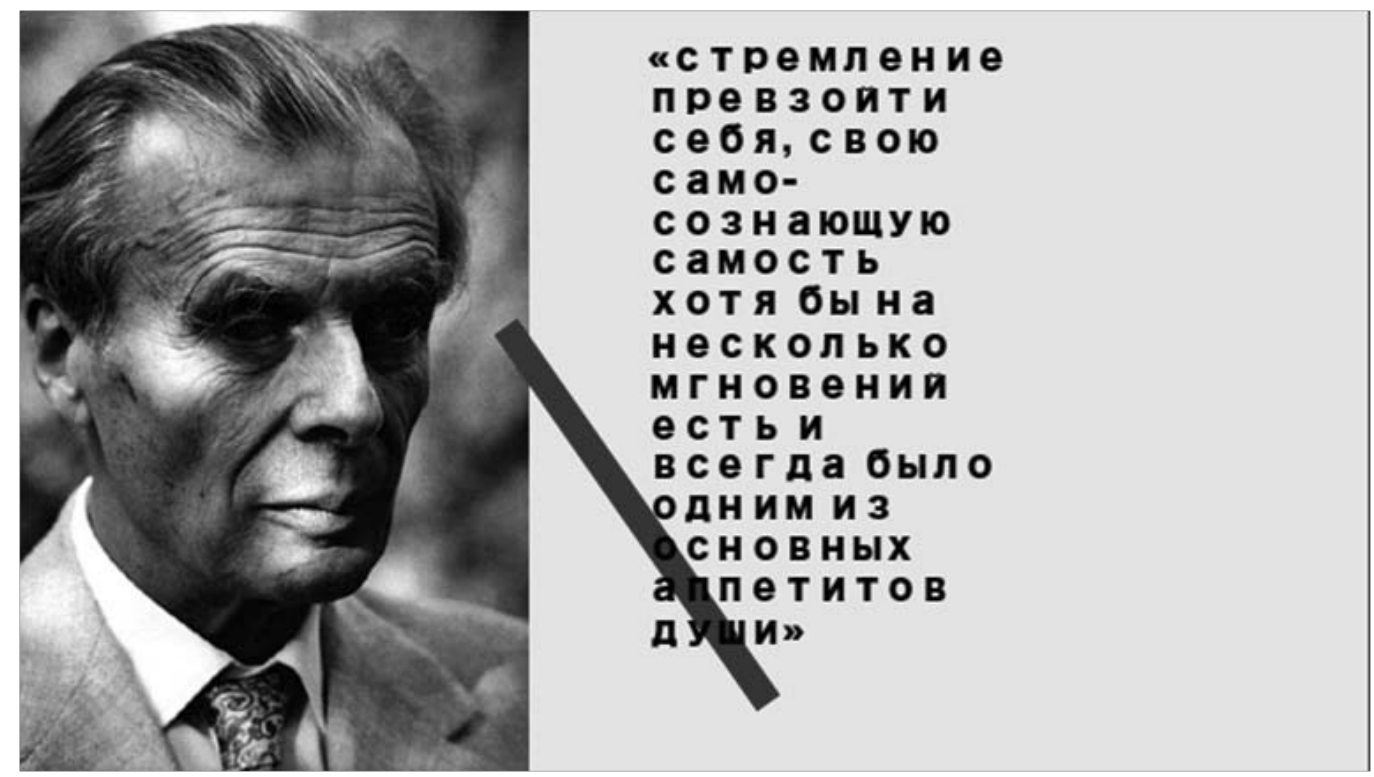

Рис. 11. Олдос Хаксли

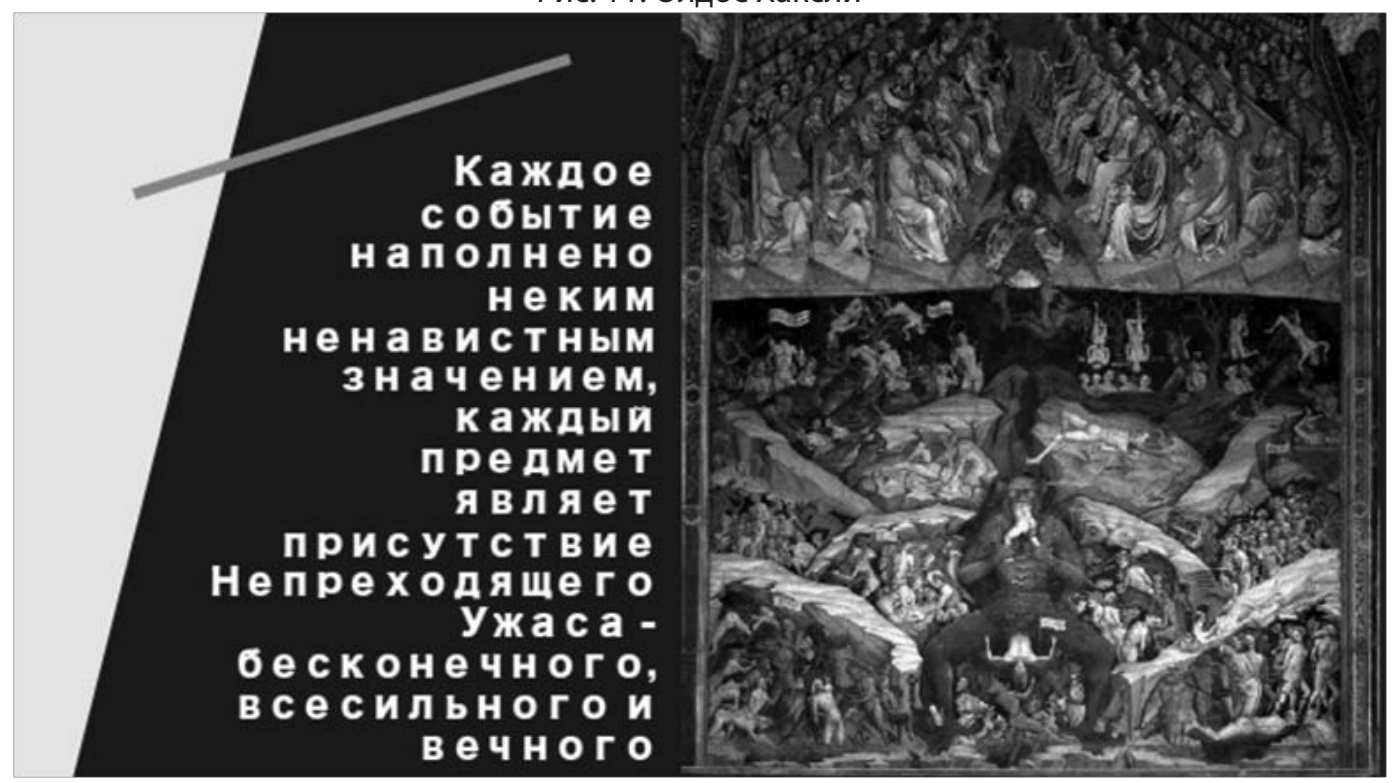

Рис. 12. Апокалиптические ожидания

тивистов (Дж. Д. Льоис-Уильямс, Т. Доусон, Р.. К. Сигель, М. Е. Джарвик, Д. Дронфилд и др.) Эти исследователи полагали, что визионерство стоит подразделять на немидикаментозно инспирированное, к которому относятся врожденная способность медиума, редкие спонтанные проявления визионерства; гипноз или аутосуггестия; болезнь или сильная усталость; сенсорная изоляция; пост, аскетические практики самоистязания - «наложенное на самих себя наказание может оказаться дверью в рай» [13, с. 106], и медикаментозное (употребление психоактивных веществ). Для этой школы характерно относить визионерство к психиатрической симптоматике: «как симптомы серьезных психических заболеваний, хотя и не имеется адекватного медицинского объяснения и лабораторных данных, подкрепляющих такую позицию». [2. - C. 233]
В любом случае, как пишет Хаксли, все эти практики «понижая эффективность мозга как редукционного клапана», дают возможность выйти за рамки «мира моральных суждений и утилитарных соображений», позволяя «узреть... внешний и внутренний миры не такими, какими они кажутся животному, одержимому выживанием, или человеку, одержимому словами и понятиями, а какими они постигаются непосредственно и, безусловно, Всем Разумом - этот опыт неоценимо драгоценен для всех (и в особенности - для интеллектуалов)" [13, с. 88], поскольку «стремление превзойти себя, свою само-сознаюшую самость хотя бы на несколько мгновений есть и всегда было одним из основных аппетитов души» [13, c. 74].

Акцентуации визионерства могут быть как беатифи- 
ческими (блаженными), так и инфернальными, и во втором случае для визионера характерны видения картин совершенно непереносимых, невозможных: «все, начиная звездами в небе и кончая пылью под ногами, невыразимо зловеще и отталкивающе. Каждое событие наполнено неким ненавистным значением, каждый предмет являет присутствие Непреходящего Ужаса - бесконечного, всесильного и вечного» [13, с. 161].

Однако, несмотря на то, что вышеперечисленные авторы, давая отличную классификацию и пописания визионерства, описывают его практически исключительно в позитивистском ключе, находя источник видений в разными образами усиленных переживаниях индивидуальных особенностей психофизиологии медиума, и практически не рассматривают социокультурную обусловленность направленности визионерского опыта, их работы подводят к выводу, что конкретизация визионерских переживаний направляется внефизиологическими факторами. Прежде всего, об этом свидетельствует то обстоятельство, отмечаемое всеми исследователями, что визионерский опыт приобретается в результате челенаправленных действий, ему можно обучить, а также закрепить и воспроизвести в специальных культурных практиках [10, с. 29].

В свою очередь, авторы, рассматривавшие визионерство как культурный феномн, от классических трудов М. Элиаде до современности (Д. Угринович, Э. Маккена, А. Сухов) неизменно выделяют в них дидактическую функцию, подчеркивая, что видения медиумов всегда были просто последующим обогащением существующих фольклорных легенд, которые в итоге вошли в рамки традиционной <...> мифологии [15, с.17].

Если рассматривать традиции европейского визионерства, то можно утверждать, что оно делится на религиозное и художественное, в зависимости от отношения медиума к собственной субъектности и от способа репрезентации видений. В традиционном религиозном визионерстве главным является суть послания, его содержание, в художественном - скорее форма, при этом в первом случае медиум склонен ощущать отсутствие творческого, порождающего начала в себе, а во втором напротив, подчеркивать значимость собственных усилий.

Религиозное визионерство стоит рассматривать, как культурную практику, отвечающую за связь материального и духовного миров, дающую возможность разрешения глобальных эсхатологических вопросов. Эта связь дает представление человеку о его месте в мире, его посмертном существовании, она настолько важна для него, что ее переживанию придается сверхзначимость. В религиозно-мифологических системах визионерская реальность обладает онтологическим статусом, пред- стает как несомненная бытийная достоверность, иначе говоря, как объективная реальность [10, с. 87].

В художественном визионерстве место потустороннего инспирирования занимает сам художник, который занимает место Бога, и творит согласно содержащимся в нем идеям[4]. При этом результат деятельности художника никогда не претендует на подлинную достоверность, он - отражение, репрезентативная форма существования идеи.

В новейшую эпоху дабл-пост мы имеем дело со сложными процессами синергетического сосуществования художественной и религиозной формы визионерства, что идеально проявляется в рассмотренном примере всемирной популярности Греты Тунберг, как медиаконы и культурного феномена. С одной стороны, как мы могли убедиться, и апокалиптическая суть видений, и грехи человечества, как причина катастрофической ситуации в настоящем и предстоящей окончательной катастрофы, и необходимость покаяния и деятельного исправления, как возможность избежать полной гибели планеты вполне традиционны и буквально повторяют рассмотренные нами примеры предшественниц Греты. Сама фигура девочки-медиума однозначно транслирует религиозный архетип невинного ребенка-визионера, столь характерный для западноевропейского христианоцентричного культурного поля (заметим, уже неоднократно использовавшийся в различных политических и экономических целях в новейшее время), базирующийся на библейском «из уст младенцев и грудных детей Ты устроил хвалу»».

С другой стороны, в высказываниях Греты мы видим вполне модернистские амбиции художника. Её неоднократное подчеркивание собственной исключительности, инаковости, несомненно указывает на претензии к постулированию истинности ее идей, даже в том случае, если они не базируются на солидном научно-экспертном основании. «Болезнь сделала меня другой, и я считаю, что быть не такой, как все, - это дар. Это помогает мне взглянуть на вещи под другим углом. Меня трудно обмануть, я вижу вещи в истинном свете. Изо дня в день люди слушают меня [3].

Это звучит вполне в соответствии с современной существующей идеей о приоритете ценности мнения над ценностью знания, существующей внутри общезападной парадигмы тотального диктата толерантности. Её деятельность не может быть «оценена и исправлена другими экспертами» [5, с. 66], поскольку фигура Греты, и так вызывающая доверие как архетип ребенка-визионера, дополнительно защищена правилами «игры в толерантность», предписывающими безусловное уважение к публичным людям с теми или иными формами неполноценности. Также в деятельности Тунберг прослеживаются традиции перформативного акционного искусства, 


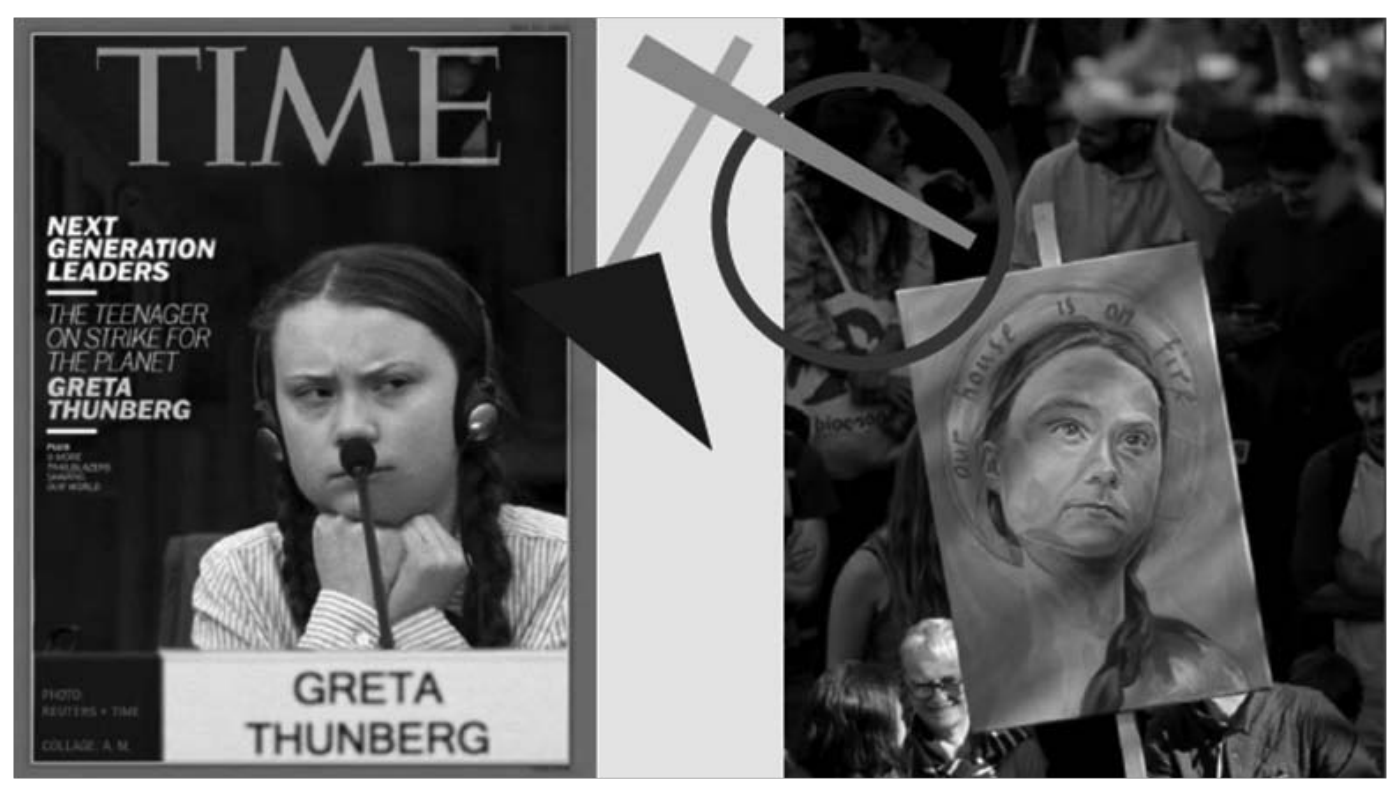

Рис. 13. Грета Тунберг -что ждет нас в будущем?

стремления к агрессивному преобразованию мира через художественную деятельность. В этом же русле лежит отождествление Греты себя, как медиума не с гласом Божьим (что, казалось, было бы естественно для дочери религиозных родителей) но с голосом поколения. Табуированность публичного упоминания идеи Бога есть еще одно из правил диктатуры толерантности: выбор одной из религиозных систем автоматически делает исповедующего её оратора противостоящим другим, а Грета хочет обращаться как можно к большему количеству слушателей. Впрочем, отдельные религиозные деятели готовы признать Грету гласом Божьим: так, лютеранская церковь в районе Лимхамн шведского города Мальмё объявила: «Иисус избрал Грету Тунберг в свои преемники». [14]

Таким образом, визионерство Греты Тунберг вполне можно охарактеризовать как симулякр, как функционирование привычного религиозного архетипа без содержания. Каково будущее у этого феномена? Скорее всего, быстрое забвение, когда мейнстрим медиаинтереса переключится на другую проблему. Кто сейчас вспоминает Северн Сузуки, которая в 12-летнем возрасте выступила с речью на конференции по экологии ООН в 1992 году, привлекая внимание общественности к проблемам озоновых дыр? Что же до реальных действий политиков, то лучше всего их иллюстрирует то, что Дональд Трамп официально объявил о выходе США из Paris Agreement, за строгое выполнение которого так ратует Тунберг.

Каково будущее визионерства в сложной, эклектичной модели современной культуры? Сложно определить, но в любом случае, исследование этого феномена способно добавить еще один элемент в общую картину.

ЛИТЕРАТУРА

1. Гроссе П., Позднякова Н. Грета Тунберг и другие: кто получил альтернативную Нобелевскую премию. // Deutsche Welle. Режим доступа: https://p. dw.com/p/306КВ (дата обращения 17.12.2019).

2. Гроф С. Космическая игра: исследование рубежей сознания. - М.: Издательство Трансперсонального Института, 1997 - 248 с.

3. Иванов. А. Дегенеративная шведская девочка как новое знамя глобального безумия. // «Завтра», 11 июня 2019. Peжим доступа: http://zavtra.ru/events/ degenerativnaya_shvedskaya_devochka_kak_novoe_znamya_global_nogo_bezumiya (дата обращения 17.12.2019).

4. Лосский Н. 0 творении мира Богом. // Журнал «Путь» №54 Режим доступа: http://www.odinblago.ru/path/54/1 (дата 0бращения 17.12.2019).

5. Николс Т. Смерть экспертизы. Как интернет убивает научные знания. М. ЭКСМ0 2019, 368 с.

6. Пастырское послание 12 января 1862 по поводу лурдских чудес епископа Невера Теодор-Огюстена Форкада // Официальная страница Лурдского санктуария. Режим доступа: http://fr.lourdes-france.org (дата обращения 17.12.2019).

7. Послание Фатимы. // Конгрегация Доктрины Веры. Режим доступа: http://www.vatican.va/roman_curia/congregations/cfaith/documents/rc_con_cfaith_ doc_20000626_message-fatima_en.html (дата обращения 07.02.2020).

8. Свящ. Луис Кондор SVD (сост.). Воспоминания сестры Лусии о Фатиме. — Фатима, 2006. — 258 с.

9. Сикари А. Портреты святых (том I, II). Милан-Москва: Христианская Россия, 1991. — 250 с.

10. Сухов А. Феномен визионерства: культурно исторические основания и модификации. Екатеринбург, 2008. - 185 с. 
11. Тяпкин П. В пылу «борьбы за климат» в Европу незаметно возращается (редневековье. // Информационное агентство Eurasia Daily. Режим доступа: https://eadaily.com/ru/news/2019/05/28/kak-v-pylu-borby-za-klimat-v-evropu-nezametno-vozrashchaetsya-srednevekove (дата 0бращения 07.02.2020).

12. Франциск: «Грета, не сдавайся» // Информационное агентство EuroNews, 18.04.2019 https://ru.euronews.com/2019/04/17/pope-with-greta (дата обращения 07.02.2020).

13. Хаксли 0. Двери восприятия. Рай и ад. - М.: АСТ, 2009. - 216 с.

14. Широкорад А. «Неужели Грета Тунберг может видеть углекислый газ?» // Независимая газета, 08.10.2019. Режим доступа: http://www.ng.ru/ vision/2019-10-08/7_7696_clairvoyant.html?fbclid=IwAR2CUZR03610WUluEFPawZqbloHlhZgyrPuxMqTPZQlzyC73_0QW7vAQoKU

15. Элиаде М. Шаманизм: Архаические техники экстаза. - М.: София, 2000. - 480 с.

16. Ямпольский М. Ткач и визионер: Очерки истории репрезентации, или 0 материальном и идеальном в культуре. М.: Новое литературное обозрение, 2007. -616 C.

17. Barthas C. Fatima, Unprecedented Miracle, Fatima, 1943. 19170 Seculo, article of October 15, 1917. Режим доступа: https://fatima.machado-family.com/ vol1/\#calibre_link-568 (дата обращения 05.12.2019).

18. Carrington, Damian. 'Our leaders are like children', school strike founder tells climate summit //The Guardian (4 декабря 2018). Режим доступа : https:// www.theguardian.com/environment/2018/dec/04/leaders-like-children-school-strike-founder-greta-thunberg-tells-un-climate-summit (дата обращения 07.02.2020).

19. Environment minister quits after questioning youth climate protests. // The Bulletin, 05.02.2019. Режим доступа: https://www.thebulletin.be/node/80007 (дата обращения 07.02.2020).

20. Greta Thunberg. School strike for climate - save the world by changing the rules. // TEDx Stockholm. Режим доступа: https://www.youtube.com/ watch?v=EAmmUIEsN9A Время от начала источника: 1:46. «I was diagnosed with Asperger's syndrom, OCD, and selective mutism. That basically means I only speak when I think it's necessary. Now is one of those moments...» (дата обращения 07.02.2020).

21. Guterres, António. The climate strikers should inspire us all to act at the next UN summit. // The Guardian (15 марта 2019). Режим доступа : https://www. theguardian.com/commentisfree/2019/mar/15/climate-strikers-urgency-un-summit-world-leaders (дата обращения 07.02.2020).

22. Leslie Hook Greta Thunberg: 'All my life I've been the invisible girl'// Financial Times 22.02.2019 // Режим доступа: https://www.ft.com/content/4df1b9e6-34fb11e9-bd3a-8b2a211d90d5 (дата обращения 07.02.2020).

23. Letter to Maria Teresa, Coimbra, Sept. 16, 1970. // A Little Treatise, by the Seer, on the Nature and Recitation of the Rosary: a collection of excerpts from letters of Sister Lucy written between 1969-71. Режим доступа: http://archive.fatima.org/crusader/aworldview/worldview9.аsр (дата обращения 07.02.2020).

24. 'Our house is on fire': Greta Thunberg, 16, urges leaders to act on climate // The Guardian, 25.01.2019 Режим доступа: https://www.theguardian.com/ environment/2019/jan/25/our-house-is-on-fire-greta-thunberg16-urges-leaders-to-act-on-climate (дата обращения 07.02.2020).

25. Shrine of Our Lady of the rosary of Fatima. // Cf. Documentação Crítica de Fátima, vol. Il. Fátima: Santuário de Fátima, 1999 Режим доступа: https://www.fatima. pt/en/pages/chronology-of-the-three-seers (дата обращения 09.01.2020).

() Пожаров Алексей Игоревич (Soundman.alex@gmail.com).

Журнал «Современная наука: актуальные проблемы теории и практики» 